УДК: 351.773

DOI https: / / doi.org/10.32837/yuv.v0i3.940

\author{
А. Неугодніков, \\ кандидат юридичних наук, \\ доцент кафедри адміністративного і фінансового права \\ Національного університету «Одеська юридична академія»
}

\title{
ПУБЛІЧНЕ АДМІНІСТРУВАННЯ В СФЕРІ ОХОРОНИ ЗДОРОВ'Я
}

Здоров'я української нації має бути пріоритетним для будь-якого управлінського апарату і спеціального обгрунтування дана теза не потребує. Натомість, інституційний та правовий механізми забезпечення належного стану охорони здоров'я в Україні характеризується казуїстичними тенденціями невідповідності існуючого стану здоров'я населення до моделі системи охорони здоров'я, яку намагаються впровадити в останні роки. Негативними ознаками публічного адміністрування в сфері охорони здоров'я, передусім $€$ відсутність чіткого алгоритму притягнення до відповідальності суб'єктів публічного адміністрування, зокрема це стосується закладів охорони здоров'я та відсутність структуризації охорони здоров'я за конкретними напрямками досягнення такого стану. У той час, коли міжнародна спільнота ставить за мету вирішення таких глобальних проблеми охорони здоров'я населення, як: забезпечення належного стану екології та безпечних для здоров'я харчових продуктів, мінімізація вірусних захворювань, дотримання лікувальних протоколів з врахуванням вікових, статевих, національних та особистісних факторів, вирішення психологічних порушень пов'язаних із «ігроманією та депресивними станами, вироблення нових архетипів свідомості як щодо конкретних захворювань, типу деменції, так і відносно індивідуальної відповідальності за стан здоров'я [1], Україна намагається переформатувати національну систему охорони здоров'я на основі застарілого управлінського апарату та негативного асоціювання громадянами порядку та якості отримання медичних послуг.

Публічне адміністрування в сфері охорони здоров'я не може розвиватись та функціонувати ізольовано від проблем сьогодення та наслідків суспільного розвитку. Необхідним видається вироблення як довгострокової концепції сталого розвитку системи охорони здоров'я, так і постійного моніторингу існуючих та виникаючих проблем у цій cфері.

Дослідженням проблеми управління в сфері охорони здоров'я займалися такі вчені, як: В.Б. Авер'янов, В.К. Колпаков, В.Ф. Москаленко, М.С. Музика, Л.О. Самілик, О.П. Хамходера та ряд інших. Проте, станом на теперішній час не має єдиного теоретико-правового підходу до визначення концептуальних засад публічного адміністрування у цій сфері суспільних відносин. Саме тому, метою статті $€$ окреслення особливостей публічного адміністрування в сфері охорони здоров'я та визначення пріоритетних напрямків поліпшення цієї діяльності.

Виклад основного змісту. Загалом, поняття «публічне адміністрування» не характеризується наявністю єдиного підходу до визначення його сутності. У цьому дослідженні за основу взято позицію відповідно до якої, під публічним адмініструванням розуміється регламентована законами та іншими нормативно-правовими актами діяльність суб'єктів публічного адміністрування, яку спрямовано на здійснення законів та інших норматив- 


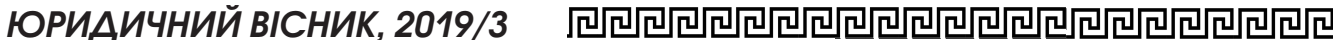

но-правових актів шляхом прийняття адміністративних рішень та надання встановлених законами послуг $[2$; 3, с. 13].

Відповідно, сутність публічного адміністрування в сфері охорони здоров'я можливо визначити на основі поєднання загальної теорії адміністративного права та специфіки сфери охорони здоров'я як регламентовану законами та іншими нормативно-правовими актами виконавчо-розпорядчу діяльність щодо охорони та забезпечення належного стану повного фізичного, психічного і соціального благополуччя шляхом прийняття адміністративних рішень та надання встановлених законами послуг в сфері охорони здоров'я.

В Україні правове забезпечення охорони здоров'я передбачено ст. $49 \mathrm{KoH}$ ституції України та виражено через такі правомочності як: право на охорону здоров'я, право на медичну допомогу, право на медичне страхування. Охорона здоров'я забезпечується державним фінансуванням відповідних соціально-економічних, медико-санітарних і оздоровчо-профілактичних програм. Щодо медичної допомоги, то держава створює умови для ефективного і доступного для всіх громадян медичного обслуговування. У державних і комунальних закладах охорони здоров'я медична допомога надається безоплатно. Також, до обов'язків держави в управлінні сферою здоров'я віднесено підтримання розвитку фізичної культури і спорту, забезпечення санітарно-епідемічного благополуччя населення [4].

Необхідність врахування викликів, які стосуються проблем забезпечення охорони здоров'я для всієї міжнародної спільноти опосередковано процесом розмивання кордонів між державами. Відсутність врахування глобальних проблем пов'язаних із здоров'ям населення призводить до фрагментарності здійснення національного публічного адміністрування в означеній сфері. Тому, необхідно зазначити, що публічне адміністрування в сфері охорони здоров'я має реалізовуватись відповідно до сукупності міжнародно-правових актів.

Так, відповідно до положень Загальної декларації прав людини, кожна людина має право на медичний догляд та необхідне соціальне обслуговування, який $€$ необхідним для підтримання здоров'я і добробуту іiі самої та іiі сім’і, і право на забезпечення в разі безробіття, хвороби, інвалідності, вдівства, старості чи іншого випадку втрати засобів до існування через незалежні від неї обставини (Ст. 25) тощо [5].

Основоположні принципи забезпечення прав людини в сфері охорони здоров'я містяться у Міжнародному пакті про економічні, соціальні і культурні права. До заходів, яких повинні вжити держави для повного здійснення права в сфері охорони здоров'я віднесено: забезпечення скорочення мертвонароджуваності та дитячої смертності і здорового розвитку дитини; поліпшення всіх аспектів гігієни зовнішнього середовища i гігієни праці в промисловості; запобігання і лікування епідемічних, ендемічних, професійних та інших хвороб і боротьби 3 ними; створення умов, які б забезпечували всім медичну допомогу і медичний догляд у разі хвороби [6].

Серед документів ВОО3 важливо звернути увагу на Декларацію про розвиток прав пацієнтів у Європі 1994 р, якою визначено вимоги, до інформаціі, що надається пацієнту, і яка має бути вичерпною. У документі зазначаються умови надання згоди на медичне втручання та умови збереження відомостей про стан здоров'я і будь-яких інших відомостей особистого характеру про пацієнта. У розділі п’ятому містяться норми, що регулюють питання надання медичної допомоги відповідно до стану здоров'я, включаючи профілактичну і лікувальну допомогу, а реалізація прав пацієнта закріплена у шостому розділі міжнародного акт [7].

Вагомого значення для публічного адміністрування у сфері охорони здоров’я мають такі міжнародно-правові 
акти, яких прийнято Всесвітньою медичною асоціацією, наприклад: Міжнародний кодекс медичної етики (1983), Декларація 3 прав людини і особистої свободи медичних працівників (1985), Декларація стосовно незалежності і професійної свободи лікаря (1986р.), Декларація стосовно ейтаназіі (1987), Хельсинська декларація; Декларація стосовно трансплантації людських органів (1987), Дванадцять принципів надання медичної допомоги у будьякій системі охорони здоров'я (1983), Заява про використання психотропних засобів і зловживання ними (1983), Декларація про жорстоке ставлення до людей похилого віку і старих (1990), Заява про політику у сфері лікування смертельно хворих пацієнтів,які відчувають хронічний біль (1990), Декларація про незалежність і професійну роботу лікаря (1986), Заява про підготовку медичних кадрів (1986) тощо [8].

Таким чином, міжнародні стандарти у сфері охорони здоров'я в публічному адмініструванні складають систему норм, які охоплюють найважливіші аспекти управлінського процесу. Дана система не є сталою, вона постійно розвивається з розвитком суспільних відносин. Наприклад, в умовах інтенсифікації технологій важливим $є$ популяризація електронної участі громадян в управлінні сферою охорони здоров'я та забезпечення якості надання медичних послуг. Для України залишається актуальним створення електронної бази з протоколами на засадах доказової медицини на українській мові. Однією 3 ключових проблем на сьогодні є боротьба з епілепсією. У цілому, епілепсія зачіпає майже 50 мільйонів людей у всьому світі, $80 \%$ із них живуть у країнах з низьким та середнім рівнем доходу, в більшості причинами є травма при народженні дитини, інфекціï мозку, травми та інсульти. Через ненормальну електричну активність у мозку, страждаючі можуть відчувати судоми або незвичайну поведінку, відчуття і іноді втрату свідомості. Необхідним $є$ включення заходів щодо про- тидії епілепсії до національних програм охорони здоров'я, наполегливо заохочувати інвестиції у зменшення іï навантаження і виступати за дії, спрямовані на подолання прогалин у знаннях, епілепсії та дослідженні [9]. При цьому, в Україні дана проблема нехтується і не вирішується. Більше того, частина хворих не має офіційно підтвердженого діагнозу хвороби через низьку кваліфікацію медичного персоналу.

Неможливо не акцентувати уваги, на міжнародно визнаній проблемі прийняття антибіотиків та прийняття їх лише у необхідних випадках, що пов'язано 3 розвитком зворотного зв'язку між бактеріями та антибіотиками. Натомість, в Україні спостерігається обов'язкове призначення антибіотиків з самого початку і бактеріальних, i вірусних захворювань. Наслідками безконтрольного вжиття антибіотиків є: неможливість лікувати серйозні та навіть поширені інфекції внаслідок втрати резистентності, неможливість здійснення операцій та підвищення їх ризику, виснаження ресурсів здоров'я [10]. ВОО3 рекомендовано впровадити до національних правових систем заходи по моніторингу використання антибіотиків, контролю по застосуванню антибіотиків у ветеринарії та сільському господарстві.

Щодо інституційного механізму публічного адміністрування в досліджуваній, то виконавчо-розпорядчу діяльність та надання послуг в сфері забезпечення належного стану повного фізичного, психічного і соціального благополуччя населення здійснюють:

1) органи охорони здоров'я загальнодержавного значення, до яких належить: Міністерство охорони здоров'я України [11] в структуру якого входять 3 департаменти, 10 управлінь, 3 відділи та 5 секторів, Національна служба здоров'я України, яка є центральним органом виконавчої влади, діяльність якого спрямовується і координується Кабінетом Міністрів України через Міністра охорони здоров'я, який реалізує державну політику у сфері державних 


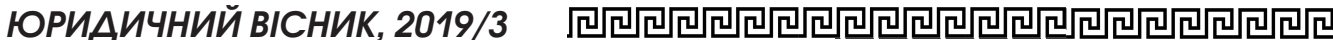

фінансових гарантій медичного обслуговування населення [12];

2) органи охорони здоров'я місцевого значення, до яких належать: місцеві державні адміністрації в рамках повноважень, яких передбачено законом [13], сільські, селищні, міські ради та їх виконавчі органи, а також районні та обласні ради, які представляють спільні інтереси територіальних громад сіл, селищ, міст в сфері охорони здоров'я [14];

3) заклади охорони здоров'я (юридичні особи будь-якої форми власності та організаційно-правової форми або іiі відокремлений підрозділ, що забезпечують медичне обслуговування населення на основі відповідної ліцензії та професійної діяльності медичних (фармацевтичних) працівників [15]. Серед них особливе місце займають санаторно-курортні заклади [16, 17];

4) громадські об'єднання, які діють 3 метою збереження та відновлення фізіологічних і психологічних функцій, оптимальної працездатності та соціальної активності людини при максимальній біологічно можливій індивідуальній тривалості іiі життя [18].

Необхідним видається звернення уваги на недоліки системи суб̆єктів, які здійснюють діяльність в сфері охорони здоров'я. Так, доцільно створити Державну інспекцію з питань якості медичних послуг. До компетенції цього органу має належати; перевірка дотримання міжнародних медичних протоколів, дотримання медичної етики; видача, зупинення та анулювання ліцензії на зайняття медичною практикою.

Щодо закладів охорони здоров'я, то для того, щоб юридична особа отримала статус закладу охорони здоров'я необхідним $€$ дотримання ліцензійних вимог, так як здійснення медичної практики, діяльності щодо забору пуповинної крові, інших тканин і клітин людини - це види діяльності, які підлягають обов'язковому ліцензуванню [18]. Зокрема, необхідним є: отримання ліцензії, що можливо у разі дотримання організаційних, кадрових і технологічних вимог до матеріально-технічної бази, обов'язкових для виконання під час провадження господарської діяльності $з$ медичної практики, а також при наявності вичерпного переліку документів, що додаються до заяви про отримання ліцензії на провадження господарської діяльності 3 медичної практики [19]. Крім того, необхідним $€$ підтвердження акредитації закладом охорони здоров'я як офіційне визнання наявності у суб'єкта умов для якісного, своєчасного, певного рівня медичного обслуговування населення, дотримання ним стандартів у сфері охорони здоров'я, відповідності медичних (фармацевтичних) працівників єдиним кваліфікаційним вимогам [20].

Щодо міжнародної практики реформування системи охорони здоров'я, суперечливим є досвід США, де функціонує розгалужена мережа приватних закладів охорони здоров'я, а медичне обслуговування надають або за пряму оплату або за рахунок коштів приватного страхування здоров'я. Діяльність державних і муніципальних медичних закладів спрямована на благодійництво та підтримку незахищених верств населення. Тому значний обсяг медичної допомоги в даній країні надають на платній основі, й приватні кошти становлять більше $58 \%$ усіх витрат на охорону здоров'я. 3 них близько $27 \%$ - пряма особиста оплата населення за медичні послуги, і майже $32 \%$ - це кошти, які надходять через систему приватного страхування здоров'я. Особливість американської системи охорони здоров'я полягає в тому, що держава диференційовано підходить до забезпечення медичних потреб населення шляхом розробки цільових програм соціального страхування. Державне фінансування адресних програм медичного обслуговування базується на поєднанні двох основних джерел фінансування: коштів бюджету та обов'язкового медичного страхування. Характерною ознакою організації системи охорони здоров'я у США є розмежування функцій вироб- 


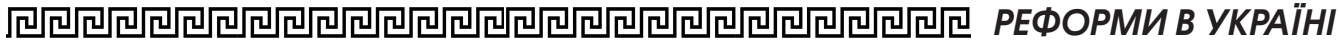

ництва медичних послуг та їх фінансування. Питання про те, хто має надавати медичні послуги (чи то державні некомерційні, чи комерційні установи охорони здоров'я), відокремлюють від проблеми фінансування. Такий підхід гарантує рівні можливості в отриманні медичної допомоги як для пацієнтів державних програм, так і для пацієнтів, застрахованих у порядку приватного медичного страхування, однак на практиці цей механізм не завжди спрацьовує [21].

Для України корисним буде проведення кардинального реформування системи охорони здоров'я 3 обов'язковим зверненням уваги на правосвідомість населення щодо отримання медичних послуг. Актуальним для України є запровадження такої системи охорони здоров'я, яка передбачатиме конкуретні засади щодо якості надання медичних послуг. Вказане новвоведення безумовно покращить стан функціонування закладів охорони здоров'я.

Висновки. Таким чином, пропонується використання комплексного підходу реформування публічного адміністрування в системі охорони здоров'я, якого засновано на врахуванні глобалізаційних процесів. Як наслідок, необхідно впровадити наступні заходи: вироблення Концепції протидії епілепсіі та надання допомоги хворим на епілепсію; впровадження обов'язковості перевірки надання антибіотиків у відповідності до міжнародних медичних протоколів; створення Державної інспекції з питань якості надання медичних послуг, до компетенції якої має належати; перевірка дотримання міжнародних медичних протоколів, дотримання медичної етики, видача, зупинення та анулювання ліцензії на зайняття медичною практикою тощо. Прийняття національного плану дій щодо підвищення рівня фізичної активності має виражати поєднання нормативних (правових та міжнародно-правових основ регулювання сфери охорони здоров'я), управлінських (менедж- мент функціонування публічної влади в сфері охорони здоров'я, особливості структурної побудови суб'єктів публічного адміністрування) соціально-культурних (стан сформованих архетипів культури здоров'я, наявність безпечних для здоров'я умов життя) детермінант належного врядування.

У статі проаналізовано відповідність стану системи охорони здоров'я до реальних потреб населення. Формальне закріплення міннародних стандартів в означеній сфері не наділяе послуги в сфері охорони здоров'я ознаками доступності та якоcmi. Можливість вільного доступу до міжнародних протоколів у відповідності до яких має здійснюватися лікування має бути на українській мові, що дозволить спростити порядок прийняття конкретних рішень в сорері охорони здоров'я та належним чином виявляти помилки, які можуть спостерігатись у медичній практиці. Сутність публічного адміністрування в сфері охорони здоров'я визначено на основі поєднання загальної теорї адміністративного права та специифіки сфери охорони здоров'я як регламентовану законами та іншими нормативно-правовими актами виконавчо-розпорядчу діяльність щодо охорони та забезпечення наленного стану повного фізичного, психічного і соціального благополуччя иляхом прийняття адміністративних рішень та надання встановлених законами послуг в сфері охорони здоров'я. Результати дослідження актуальні для вітчизняних законодавців та суб'єктів, які здійснюють публічне адміністрування в сфері охорони здоров'я на тлі актуалізації тенденцій демократизаціі управлінських прочесів в Україні. У иій статmі вперше досліджуються глобалізаційні аспекти охорони здоров'я як системний інструмент реформування управлінського підходу в Україні. Для послідовного висвітлення проблеми 


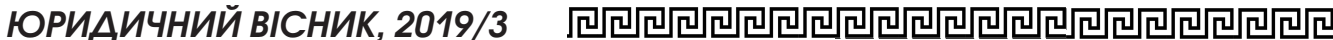

виділено окремі змістовні блоки, які характеризують однорідну групу суспільних відносин, що стосуються особливостей публічного адміністрування в сфері охорони здоров'я, а саме: інституиійно-правові засади публічного адміністрування в сфері охорони здоров'я, глобалізаційні тендениіі в сфері охорони здоров'я, міжнародно-правові засади публічного адміністрування в сфері охорони здоров'я.

Ключові слова: публічне адміністрування, охорона здоров'я, інституційний механізм, правове регулювання, реформування.

\section{Neuhodnikov \\ A. PUBLIC ADMINISTRATION IN THE HEALTHCARE SPHERE}

The purpose of this article is to establish the level of efficiency rise ways of public administration implementation in the sphere of healthcare in Ukraine on the basis of the international experience use; to define a unified conception of the institutional and legal basics' management in the sphere of healthcare and to offer specific recommendations as to the introduction into legal reality of Ukraine. In the article were determine that the low adaptation level of a present healthcare system of Ukraine to real population needs. The formal international standards consolidation in a designated sphere does not provide the services in the sphere of healthcare with the availability and quality signs. The free access ability to the international protocols, in accordance with which the treatment should be provided, has to be in Ukrainian which will allow to simplify the procedure of specific decision making in the sphere of healthcare as well as to find mistakes which can occur in medical practice in due course. The essence of public administration in the sphere of healthcare is respectively defined on the ground of the common theory combination of the administrative law and the specificity of the healthcare sphere as the regulated by the law and by the other normative-legal acts executive-administrative activity on the protection and provision with the proper state of physical, mental and social welfare by means of the administrative decrees adoption and the statutory healthcare services provided. The research results are relevant for domestic lawmakers and entities which carry out the public administration in the sphere of healthcare against a background of the tendencies actualization of administrative processes democratization in Ukraine. The global aspects of the healthcare protection as a systematic instrument of the managerial approach reformation in Ukraine are first examined in this article. For a consistent problem coverage there are allotted separate informative blocks which characterize the uniform group of social relations concerning the features of public administration in the sphere of healthcare namely, the institutionallegal basics of public administration in the sphere of healthcare, global tendencies in the sphere of healthcare, international-legal basics of public administration in the sphere of healthcare.

Key words: public administration, health care, institutional mechanism, legal regulation, reform.

\section{Література:}

1. Официальный сайт Всемирной организации здравоохранения (ВОO3). URL: https: / / wrw.who.int/home

2. Чернов C.I. Текст лекиій з дисизпліни «Публічне адміністрування» (для студентів всіх форм навчання за спеціальністю 7.03060101, 8.03060101 «Менеджмент організацій $i$ адміністрування (за видами економічної діяльності). Харк. наи. ун-т міськ. госп-ва ім. О.М. Бекеmова. Х.: ХНУМГ, 2014. 97 c. URL: http: // eprints.kname.edu.ua/35679/1/\%D0\%9A $\%$ D O \% BE\% DO \% BD D $1 \% 81 \% D 0$ $\%$ BF D O \% B 5\% D0\% BA\% D $1 \% 82 \% 20$ $\%$ D0\% 1\% 86\% D 1\% $96 \%$ D0\% B $9 \% 20$ $\%$ D0\% $9 F \%$ D0\% 90 . pdf

3. Бондаренко K.В, Государственное управление и публичное администрирова- 


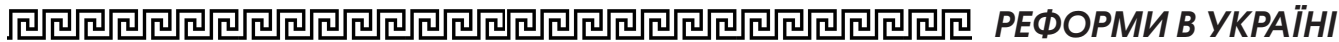

ние - соотношение понятий. Legeasi Viata. 2017. № 3. Cm. 10-13.

4. Конституція України: Закон України від 28.06.1996 р. Відомості Верховної Ради України. 1996. № 30. Ст. 141.

5. Загальна декларація прав людини: Міжнародний документ від 10.12.1948 p. Офінійний вісник України. 2008. № 93. Ст.89.

6. Міжнародний пакт про економічні, соиіальні і культурні права: Міжнародний документ віة 16.12.1966 p. URL: https: / / zakon.rada.gov .ua/laws/show/995_042

7. Декларація про розвиток прав nauiєнmis y Esponi. URL: http://www.i rf.ua/files / ukr/programs / euro/patients_ brochure.pdf

8. Офічійний сайт Верховної Ради України. URL: https: / / zakon.rada.gov.ua/ lares / main / c43

9. Epilepsy: a public health imperative. Geneva: World Health Organization; 2019. Licence: CC BY-NC-SA 3.0 IGO. URL: https: / / wrw.who. int/mental_health / neurology / epilepsy / report_2019/en /

10. Adopt AWaRe: Handle antibiotics with care, 2019 https://adoptaware.org/ resources / $A W a R e \_B r o c h u r e . p d f$

11. Про затвердження Положення про Міністерство охорони здоров'я України: Постанова Кабінету Міністрів України від 25.03.2015 № 267. Офінійний вісник України. 2015. № 38. Cm. 86.

12. Положення про Національну службу здоров'я України: Постанова Кабінету Міністрів України від 27.12.2017. Офіщійний вісник України. 2018. № 15. Ст. 29.

13. Про місиеві державні адміністраиії: Закон України від 09.04.1999 р. Офіиійний вісник України. 1999. № 20. Ст. 190.

14. Про місцеве самоврядування в Україні: Закон України від 21.05.1997 р. Офіцій- ний вісник України. 1999. № 25. Ст. 20.

15. Основи законодавства України про охорону здоров'я: Закон Украіни від 19.11.1992 р. Відомості Верховної Ради України. 1993. № 4. Ст. 19.

16. Про курорти: Закон України від 05.10.2000 р. Відомості Верховної Ради України. 2000. № 50. Cm. 435.

17. Про затвердження Загального положення про санаторно-курортний заклад: Постанова Кабінету Міністрів України від 11.07.2001 № 805. Офіційний вісник Украіни. 2001. № 28. Cm. 78 .

18. Про забезпечення участі громадськості у формуванні та реалізації державної політики: Постанова Кабінету Міністрів України від 3 листопада 2010 р. № 996. Офіційний вісник України 2010. № 84. Cm. 36 .

19. Про лішензування видів господарської діяльності: Закон України від 02.03 .2015 р. Відомості Верховної Ради України. 2015. № 23. Ст. 1234.

20. Про затвердження Ліцензійних умов провадження господарської діяльності з медичної практики: Постанова Кабінету Міністрів України від 02.03.2016 р. Офіційний вісник України. 2016. № 30. Ст. 18.

21. Про затвердження Порядку акредитації закладу охорони здоров'я: Постанова Кабінету Міністрів України від 15.07.1997 № 765. Офіційний вісник України. 1997. № 29. Cm. 61 .

22. Карпищин Н., Комуніцька М. Класичні моделі фінансового забезпечення охорони здоров'я. Світ фінанciв. 2008. № 1. http://dspace.tneu.edu. ua / bitstream / $316497 / 26425$ / 1/\% D $0 \% 9 A \%$ D0\% $90 \%$ DO $\%$ AO $0 \%$ DO $9 F \%$ DO\% 98\% D0\% A8\% D0\% 98\% D0\% 9D.pdf 